\title{
Exposure to crocidolite and the incidence of different histological types of lung cancer
}

\author{
Nicholas H de Klerk, A William Musk, Jan L Eccles, Janice Hansen, Michael ST Hobbs
}

\begin{abstract}
Objectives-To estimate the relations between exposure to both tobacco smoke and crocidolite and the incidence of various histological types of lung cancer. Methods-In 1979 all former workers from the Wittenoom asbestos industry who could be traced were sent a questionnaire on smoking history. Of 2928 questionnaires sent, satisfactory replies were received from 2400 men and 149 women. Of the men, $80 \%$ had smoked at some time and $\mathbf{5 0 \%}$ still smoked. Occupational exposure to crocidolite was known from employment records and follow up was maintained through death and cancer registries in Australia with histological diagnoses obtained from the relevant State Cancer Registry. Conditional logistic regression was used to estimate the effects of tobacco and asbestos exposure on incidence of different cell types of lung cancer in a nested case-control design.

Results-Between 1979 and 1990, 71 cases of lung cancer occurred among men in this cohort: $27 \%$ squamous cell carcinoma, $31 \%$ adenocarcinoma, $18 \%$ small cell carcinoma, $11 \%$ large cell carcinoma, and $13 \%$ unclassified or indeterminate. Two of the classified cases and one unclassified case had never smoked. The incidence of both squamous and adenocarcinoma types of lung cancer were greatest in exsmokers and in those subjects with the highest levels of exposure to crocidolite. After adjustment for smoking habit, the increase in incidence of lung cancer with increasing exposure to crocidolite was greater for squamous cell carcinoma than for adenocarcinoma.

Conclusions-The results from this study have shown significant exposure-response effects for exposure to crocidolite, and both adenocarcinoma and squamous cell carcinoma of the lung. They also provide some further evidence against the theory that parenchymal fibrosis induced by asbestos is a necessary precursor to asbestos induced lung cancer.
\end{abstract}

(Occup Environ Med 1996;53:157-159)

Keywords: asbestos; smoking; exposure-response

Previous studies of lung cancer in workers exposed to asbestos have shown that the proportions of adenocarcinoma or squamous cell carcinoma predominate, raising the possibility that one or other (or both) may be more commonly related to asbestos. ${ }^{1}$ Smoking and exposure to asbestos have been shown to act together almost multiplicatively on the risks of lung cancer in subjects exposed to mixtures of types of asbestos ${ }^{2}$ as well as to crocidolite alone. ${ }^{3}$ Little else is known about the way the two agents act together to cause lung cancer and particularly what their relations with the different histological types of lung cancer are. It has even been suggested that smoking and asbestos exposure are associated with different histological types of lung cancer-that is, squamous cell carcinoma with smoking and adenocarcinoma with asbestos. ${ }^{45}$ In earlier work it was shown that squamous cell lung cancer was proportionately more common in Wittenoom workers than in the rest of the population of Western Australia ${ }^{6}$ but in other series of lung cancers in asbestos workers adenocarcinoma has been more common, ${ }^{7}$ supporting theories that asbestosis is a necessary precursor of lung cancer caused by asbestos, as adenocarcinoma is associated with other lung scarring diseases such as fibrosing alveolitis. It is only if valid and significant doseresponse relations can be established for either or both types of lung cancer after adjustment for smoking, that this question can be adequately answered.

Between 1943 and 1966, 6500 men and 410 women were known to have been employed in the Wittenoom crocidolite industry. Their median duration of employment was four months and median cumulative exposure to crocidolite was six fibres $/ \mathrm{ml}$ ( $\mathrm{f} / \mathrm{ml})$.years. ${ }^{8}$ A mortality study of this cohort has shown increased death rates from malignant mesothelioma, lung cancer, and asbestosis, as well as diseases related to smoking and alcohol. ${ }^{9}$ Follow up of the subcohort who completed a questionnaire on smoking and other exposures in 1979 has been completed to December 1991. All known incident cases of cancer of all sites and all deaths from all causes were documented. This study aims to examine the exposure-response relations between exposure to crocidolite and tobacco smoke and the incidence of different histological types of lung cancer.

Subjects and methods SUBJECTS

In the crocidolite industry at Wittenoom 6500 men were employed between 1943 and 1966 . In 1979 addresses were traced for 2928, and 
2400 replied to a questionnaire on smoking and occupational exposures and constitute the cohort for this study.

\section{METHODS}

Certified cause of death was obtained from the Registrar General's office in all states of Australia up to December 1991. Incident cases of cancer have been identified at the Western Australia Cancer Registry to December 1991. The histological type of cancer for each person was determined at the registry from all available pathology and cytology reports for each individual case. These were obtained from pathology laboratories and coroners' records.

Duration, degree, and period of exposure to crocidolite were found from employment histories and dust measurements in the industry as already described. ${ }^{8}$

Cases of lung cancer were matched to all subjects from the cohort who were not known to have developed cancer of this site by the year of diagnosis of the case, who were the same age and who were known to be alive at the time of diagnosis of the case. Subjects could be controls for more than one case and cases could be controls in years before the onset of their disease. Numbers of controls per case varied from 12 to 117 .

Variables compared between cases and controls were smoking, mean intensity of crocidolite exposure $(\mathrm{f} / \mathrm{ml})$, duration of crocidolite exposure (days), time since first exposure (years), year of birth, year started work (before 1950, 1950-56, after 1956), cumulative crocidolite exposure, and work site (mill only, mill and elsewhere (including mine and unknown), mine only, mine and elsewhere (not including mill), neither mine nor mill, and unknown). Continuous variables were also categorised to examine non-linearity of effects.

Smoking habit was categorised as that given on the questionnaire and was assumed not to change throughout the study. For exsmokers it

Table 1 Exposure to asbestos and cigarette smoke for cases and controls

\begin{tabular}{|c|c|c|c|c|c|c|}
\hline & Controls* & SCC & $A D C$ & SCell & LCell & All cases \\
\hline $\begin{array}{l}\text { Subjects (n) } \\
\text { Crocidolite exposure: }\end{array}$ & 3163 & 19 & 22 & 13 & 8 & 71 \\
\hline $\begin{array}{l}\text { Mean duration (days) } \\
\text { Mean intensity (f/ml) } \\
\text { Mean time since first exposure (y) }\end{array}$ & $\begin{array}{l}388 \\
25 \cdot 2 \\
29 \cdot 3\end{array}$ & $\begin{array}{l}781 \\
38 \cdot 4 \\
29 \cdot 5\end{array}$ & $\begin{array}{l}492 \\
34 \cdot 7 \\
28 \cdot 6\end{array}$ & $\begin{array}{l}669 \\
15 \cdot 5 \\
28 \cdot 5\end{array}$ & $\begin{array}{l}202 \\
55 \cdot 0 \\
29 \cdot 5\end{array}$ & $\begin{array}{l}580 \\
34 \cdot 4 \\
29 \cdot 0\end{array}$ \\
\hline $\begin{array}{l}\text { Smoking category: } \\
\text { Never smoked } \\
\text { Ex }>10 \mathrm{y} \\
\text { Ex } 6-10 \mathrm{y} \\
\text { Ex }<6 \text { y } \\
\text { Current }<20 / \text { day } \\
\text { Current } \geqslant 20 / \text { day }\end{array}$ & $\begin{array}{r}\% \\
23 \cdot 5 \\
24 \cdot 2 \\
5 \cdot 1 \\
3 \cdot 3 \\
18 \cdot 6 \\
25 \cdot 3\end{array}$ & $\begin{array}{r}\% \\
5 \cdot 3 \\
5 \cdot 3 \\
5 \cdot 3 \\
10 \cdot 5 \\
15 \cdot 8 \\
57 \cdot 9\end{array}$ & $\begin{aligned} \% \\
0 \\
22 \cdot 7 \\
9 \cdot 1 \\
4 \cdot 5 \\
31 \cdot 8 \\
31 \cdot 8\end{aligned}$ & $\begin{array}{l}\% \\
7 \cdot 7 \\
0 \\
15 \cdot 4 \\
15 \cdot 4 \\
15 \cdot 4 \\
46 \cdot 2\end{array}$ & $\begin{array}{l}\% \\
0 \\
0 \\
12 \cdot 5 \\
0 \\
37 \cdot 5 \\
50 \cdot 0\end{array}$ & $\begin{array}{r}\% \\
3 \cdot 2 \\
9 \cdot 7 \\
9 \cdot 7 \\
8 \cdot 1 \\
24 \cdot 2 \\
45 \cdot 2\end{array}$ \\
\hline
\end{tabular}

SCC = squamous cell; ADC = adenocarcinoma; SCell = small cell; LCell $=$ large cell anaplastic.

${ }^{\star}$ Mean of the mean of each set of matched controls.

Table 2 Relative risks of lung cancer and exposure to crocidolite (adjusted for smoking)

\begin{tabular}{lll}
\hline Type of cancer & $\begin{array}{l}R R(95 \% C I) \\
\left(\log _{e}\right) \text { cumulative exposure }(\mathrm{f} / \mathrm{ml} . y)\end{array}$ & Cases/controls \\
\hline Squamous cell carcinoma & $1 \cdot 5(1 \cdot 1-2 \cdot 0)$ & $19 / 1110$ \\
Adenocarcinoma & $1 \cdot 3(1 \cdot 0-1 \cdot 7)$ & $22 / 1132$ \\
Undifferentiated large cell cancer & $2 \cdot 1(1 \cdot 0-4 \cdot 3)$ & $8 / 436$ \\
Small cell cancer & $1 \cdot 1(0 \cdot 8-1 \cdot 6)$ & $13 / 754$ \\
All lung cancer & $1 \cdot 4(1 \cdot 2-1 \cdot 6)$ & $71 / 3163$ \\
\hline
\end{tabular}

was therefore assumed that the time since they had last smoked was the time between giving up and the time of diagnosis of their disease or that of the matched case.

The frequencies of the variables of interest in the matched sets of cases and controls were compared with conditional logistic regression analysis to estimate odds ratios by use of the computer program Egret $^{10}$ and the odds ratio was taken to approximate to the relative risk or rate ratio. For tabular presentations, because cases were matched to sets of controls of varying sizes, variables were averaged across each control set before taking the overall average.

\section{Results}

There were 22 cases of adenocarcinoma, 19 squamous cell cancers, 13 small cell and eight large cell undifferentiated carcinomas, nine cases had no specific cell type recorded and were only included in the analysis for all lung cancers. All groups of cases included fewer non-smokers than did the controls and they also tended to have received less exposure to crocidolite (table 1).

Apart from small cell cancer, all cell types of cancer were significantly associated with log cumulative exposure to asbestos. Large cell anaplastic cancers had the highest relative risk, increasing $2 \cdot 1$-fold for each $\log \mathrm{f} / \mathrm{ml}$.year of exposure, but none of the estimated relative risks for any of the four types of cancer, or for all lung cancers, were significantly different from each other (table 2). Effects of exposure on all lung cancers were similar to those found previously ${ }^{3}$ with risk increasing $1 \cdot 4$-fold for each $\log \mathrm{f} / \mathrm{ml}$.year of exposure.

The highest relative risks of smoking on lung cancer were found in people who had recently stopped smoking and there was a dose-response effect in current smokers for squamous cell and small cell cancers (table 3 ). There seemed to be no effect of smoking on undifferentiated large cell cancers in this study, and although there were significant effects of smoking on adenocarcinoma, they were much less than for the other types and were uniform in all smoking categories.

No other exposure or demographic variables had a significant effect on incidence of lung cancer apart from time from first exposure when all lung cancers were combined (table 4). This analysis also indicated a slightly better fit when intensity of exposure and log days of exposure were used instead of $\log$ cumulative exposure. No significant $(P<0 \cdot 20)$ interaction terms between smoking and effects of asbestos exposure were found.

\section{Discussion}

Exposure to crocidolite is significantly related to the incidence of adenocarcinoma of the lung, squamous cell lung cancer, and undifferentiated large cell lung cancer among these former Wittenoom workers. These findings are similar to previous results from the Wittenoom cohort ${ }^{6}$ but contrast with results from a Danish study of workers exposed 
Table 3 Relative risks of lung cancer and smoking habit compared with non-smokers and exsmokers of $>10$ years duration (adjusted for exposure to asbestos)

\begin{tabular}{|c|c|c|}
\hline & $R R(95 \% C I)$ & Cases/controls \\
\hline $\begin{array}{l}\text { Squamous cell carcinoma: } \\
\text { Exsmoker }<10 \text { y } \\
\text { Current smoker }(0-19 / \text { day }) \\
\text { Current smoker }(\geqslant 20 / \text { day }\end{array}$ & $\begin{array}{r}10 \cdot 5(1 \cdot 4-78 \cdot 7) \\
3 \cdot 5(0 \cdot 6-21 \cdot 2) \\
9 \cdot 7(2 \cdot 1-44 \cdot 2)\end{array}$ & $19 / 1110$ \\
\hline $\begin{array}{l}\text { Adenocarcinoma: } \\
\text { Exsmoker }<10 \text { y } \\
\text { Current smoker }(0-19 / \text { day }) \\
\text { Current smoker }(\geqslant 20 / \text { day })\end{array}$ & $\begin{array}{l}3.5(0.8-16.4) \\
3.8(1.2-12.4) \\
3.2(1.0-10.7)\end{array}$ & $22 / 1132$ \\
\hline $\begin{array}{l}\text { Undifferentiated large cell cancer: } \\
\text { Exsmoker }<10 \text { y } \\
\text { Current smoker }(0-19 / \text { day }) \\
\text { Current smoker }(\geqslant 20 / \text { day })\end{array}$ & $\begin{array}{l}1 \cdot 0- \\
2 \cdot 1(0 \cdot 2-25 \cdot 8) \\
0 \cdot 7(0 \cdot 1-7 \cdot 9)\end{array}$ & $8 / 436$ \\
\hline $\begin{array}{l}\text { Small cell cancer: } \\
\text { Exsmoker }<10 \text { y } \\
\text { Current smoker }(0-19 / \text { day }) \\
\text { Current smoker }(\geqslant 20 / \text { day })\end{array}$ & $\begin{array}{c}14.7(1.4-151 \cdot 9) \\
5 \cdot 2(0.5-58 \cdot 5) \\
8.9(1.0-78 \cdot 2)\end{array}$ & $13 / 754$ \\
\hline $\begin{array}{l}\text { All lung cancer: } \\
\text { Exsmoker }<10 \text { y } \\
\text { Current smoker }(0-19 / \text { day }) \\
\text { Current smoker }(\geqslant 20 / \text { day })\end{array}$ & $\begin{array}{l}9 \cdot 2(3 \cdot 2-26 \cdot 5) \\
5 \cdot 7(2 \cdot 2-14 \cdot 7) \\
7 \cdot 8(3 \cdot 3-18 \cdot 6)\end{array}$ & $71 / 3163$ \\
\hline
\end{tabular}

principally to chrysotile, which found the strongest relation to be between adenocarcinoma and exposure to asbestos. ${ }^{7}$ A population based study from Poland however, although not restricted solely to asbestos workers, found comparable relative risks to those presented here, with squamous cell carcinoma the most strongly related to duration of exposure to mineral dust. ${ }^{11}$ All these studies as well as others ${ }^{12}$ have, however, found a strong relation between exposure to asbestos and squamous cell lung cancer, only the relative magnitudes of the effects were different.

Smoking was also related to the incidence of most histological types of lung cancer, but particularly to squamous cell carcinoma in this group as in many others. ${ }^{13}$ The relative risk models fitted here imply a multiplicative association between exposure to asbestos and tobacco in the cause of lung cancer, as discussed previously. ${ }^{3}$ The decline in relative risk more than 25 years after first exposure was similar to that found before and indicates that crocidolite probably acts at a late stage in carcinogenesis.

Table 4 Association between exposure to crocidolite and cigarettes and incidence of all lung cancer types combined

\begin{tabular}{lc}
\hline & $R R(95 \% \mathrm{CI})$ \\
\hline Crocidolite exposure: & $1 \cdot 42(1 \cdot 14-1 \cdot 76)$ \\
Duration $\log ($ days $)$ & $1 \cdot 01(1 \cdot 00-1 \cdot 02)$ \\
Intensity $(\mathrm{f} / \mathrm{ml})$ & \\
& \\
Time since first exposure: & $1 \cdot 00$ \\
$0-20 \mathrm{y}$ & $0 \cdot 96(0 \cdot 34-2 \cdot 75)$ \\
$21-25 \mathrm{y}$ & $0 \cdot 28(0 \cdot 09-0 \cdot 94)$ \\
$26-30 \mathrm{y}$ & $0 \cdot 62(0 \cdot 19-2 \cdot 03)$ \\
$\geqslant 31$ y & \\
Smoking category: & $1 \cdot 0$ \\
Never smoked & $2 \cdot 2(0 \cdot 4-11 \cdot 9)$ \\
Ex $>10 \mathrm{y}$ & $12 \cdot 1(2 \cdot 2-65 \cdot 3)$ \\
Ex 6-10 y & $25 \cdot 1(4 \cdot 3-146 \cdot 2)$ \\
Ex $<6 \mathrm{y}$ & $9 \cdot 6(2 \cdot 1-43 \cdot 1)$ \\
Current $<20 /$ day & $13 \cdot 1(3 \cdot 1-56 \cdot 3)$ \\
Current $\geqslant 20 /$ day &
\end{tabular}

In our previous histological study, ${ }^{6}$ to ensure consistency of diagnosis, all histological material was reviewed by a single pathologist who was blinded to the original diagnosis, whereas in this study the cell type decided on by the cancer registry was used (usually that nominated by the diagnosing pathologist). The previous study found close agreement between the diagnosing pathologist and the single study pathologist so the exercise was not repeated. As the diagnoses came from multiple pathologists, possible bias due to the source of the histological material should have been minimised.

The results of this study offer considerable support in discounting the contention that lung cancer can only be attributed to asbestos exposure if there is evidence of pre-existing asbestosis, ${ }^{14}$ as it seems unlikely that cancers arising in the tissues of conducting airways should be caused by the presence of diffuse interstitial pulmonary fibrosis of the lung parenchyma, which is composed of different cell types. This view is supported by the results from a recent case-control study in London. ${ }^{15}$

This work was supported by the Australian National Health and Medical Research Council. Assistance with the estimation of exposure levels was kindly provided by $\mathrm{Mr} \mathrm{G}$ Major and $\mathrm{Mr} \mathrm{O}$ Allan. The assistance of Dr BK Armstrong, Mrs B Blunsdon, Mr A Lebrasse, Mrs L Kroll, Mr S Woodward, and Dr J Baker Mr A Lebrasse, Mrs L Kroll, Mr S Woodward, and Dr J Baker
in the collection of data for this report is gratefully acknowlin the
edged.

1 McDonald AD, McDonald JC. Epidemiology of asbestos related lung cancer. In: Antman $\mathrm{K}$, Aisner $\mathrm{J}$, eds. Asbestos-related malignancy. Orlando, Florida: Grune and Stratton, 1987:57-79.

2 Berry G, Newhouse ML, Antonis P. Combined effect of asbestos and smoking on mortality from lung cancer and mesothelioma in factory workers. $\mathrm{Br} \mathcal{F}$ Ind Med 1985; 42:12-8.

3 de Klerk NH, Musk AW, Armstrong BK, Hobbs MST. Smoking, exposure to crocidolite, and the incidence of Smoking, exposure to crocidolite, and the incidence of

4 Doll $\mathrm{R}$, Hill AB. Mortality in relation to smoking. BMF 1964;i:1399-410.

5 Whitwell F, Newhouse ML, Bennett DR. A study of histological types of lung cancer in workers suffering from asbestosis in the UK. Br F Ind Med 1974;31:298-303.

6 Baker JE, Reutens DC, Graham DF, Sterrett GF, Musk AW, Hobbs MS, et al. Morphology of bronchogenic carcinoma in workers formerly exposed to crocidolite at Wittenoom Gorge in Western Australia. Int $\mathcal{f}$ Cancer 1986;37:547-50

7 Raffn E, Lynge E, Korsgaard B. Incidence of lung cancer by histological type among asbestos cement workers in by histological type among asbestos cement workers in

8 Armstrong BK, de Klerk NH, Musk AW, Hobbs MST. Mortality in miners and millers of crocidolite in Western Australia. Br f Ind Med 1988;45:5-13.

9 de Klerk NH, Musk AW, Armstrong BK, Hobbs MST. Diseases in miners and millers of crocidolite from Wittenoom, Western Australia: a further follow-up to December 1986. Ann Occup Hyg 1994;38 (suppl 1): 647-55.

10 SERC. Program EGRET. Seattle, Washington: SERC, 1993.

11 Becher H, Jedrychowski W, Wahrendorf J, Basa-Cierpialek Z, Flak E, Gomola K. Effect of occupational air pollutants on various histological types of lung cancer: a population based case-control study. Br F Ind Med 1993; 50:136-42.

12 Vena JE, Byers TE, Cookfair D, Swanson M. Occupation and lung cancer risk: an analysis by histologic subtypes. Cancer 1985;56:910-7.

13 Morabia A, Wynder EL. Cigarette smoking and lung cancer cell types. Cancer 1991;68:2074-8.

14 Browne $K$. Is asbestos or asbestosis the cause of the increased risk of lung cancer in asbestos workers? $\mathrm{Br} \mathcal{F}$ Ind Med 1986;43:145-9.

15 Wilkinson P, Hansell DM, Janssens J, Rubens M, Rudd $\mathrm{RM}$, Taylor AN, McDonald C. Is lung cancer associated with asbestos exposure when there are no small opacities on the chest radiograph? Lancet 1995;345:1074-8. 